Article

\title{
The Problem of Water Use in Rural Areas of Southwestern Spain: A Local Perspective
}

\author{
Manuel Pulido ${ }^{1, * \mathbb{D}}$, Jesús Barrena-González ${ }^{1}$, Alberto Alfonso-Torreño ${ }^{1}{ }^{\mathbb{D}}$, \\ Rafael Robina-Ramírez ${ }^{2}$ (D) and Saskia Keesstra ${ }^{3}$ \\ 1 GeoEnvironmental Research Group (GIGA), University of Extremadura, 10071 Cáceres, Spain; \\ jesusbarrena@unex.es (J.B.-G.); albertoalfonso@unex.es (A.A.-T.) \\ 2 Faculty of Business and Tourism, University of Extremadura, 10071 Cáceres, Spain; rrobina@unex.es \\ 3 Soil, Water and Land Use Team, Wageningen University, 6708 PB Wageningen, The Netherlands; \\ saskia.keesstra@wur.nl \\ * Correspondence: mapulidof@unex.es; Tel.: +34-684-080-710
}

Received: 20 May 2019; Accepted: 20 June 2019; Published: 25 June 2019

\begin{abstract}
Water is a key strategic resource, particularly in Mediterranean climate-type areas with impermeable rocks and shallow soils like Southwestern Spain. The region of Extremadura is commonly known by its large surface occupied by big dams (30\% of water dammed in Spain) although this theoretical abundance of water does not hide other problems of use. In this study, we have interviewed 132 people from the municipality of Arroyo de San Serván in order to know what the problems related to water use are, especially those that concern local people the most. Regarding the use of water at home, $90 \%$ of interviewees spend less than 60 EUR per month for water and their mean degree of satisfaction about the service is 3.7 out of 7 . The reason for this low value can be the excessive content of calcium and bad taste according to $82.1 \%$. Therefore, $64.2 \%$ of people do not usually drink water from the tap. Around two thirds of these local people usually buy water in the supermarket or drink filtered water. Concerning agricultural activities, local people gave great importance to irrigation as a source of employment (5.6/7) and inputs (4.5/7), although their satisfaction decreases about the current price of water for agriculture $\left(0.02 \mathrm{EUR} \mathrm{m}^{-3}\right)$. In addition, they are really worried about the overuse of fertilizers and herbicides (5.4/7) and they think about the necessity of taking measures to reduce these problems (6.1/7) as well as to reduce some management problems such as supply cuts. In the last few years, private (swimming pools) and public leisure facilities (swimming pool and spa) have been built in spite of not being considered important by local people (3.6-4.0/7). Nevertheless, about $60 \%$ of them consider these common facilities very positive in terms of employment, tourism attractions and entertainment for local people.
\end{abstract}

Keywords: drinking water; irrigation; leisure facilities; local perception

\section{Introduction}

Nowadays, Extremadura is by far commonly known as the Spanish region with more surface occupied by freshwater, i.e., it has $30 \%$ of water dammed in the whole of Spain [1] in spite of being a Mediterranean region, where annual rainfall averages $615 \mathrm{~mm}$ (range: $400-1000 \mathrm{~mm}$ ) and snow is only a common feature in the highest mountains in the north of the region (Sierra de Gredos, Central System) [2]. The natural reason behind this ability to store water is the pass of two important rivers on the Iberian Peninsula; Tagus and Guadiana rivers.

In spite of this enormous amount of stored water, there are still many unsolved (and some not still detected) problems such as a refusal to drink tap water, conflict with the water management for irrigation, 
and wide-spread implementation of private pools that are commonly detected working at a local scale, usually forgotten by the decision makers-mostly belonging to regional or national administrations.

During the Franco dictatorship era, water infrastructures took the form of large reservoirs (maximum capacity from 88 to $3160 \mathrm{hm}^{3}$ ) thought to the generation of electricity power and to irrigate lands recently turned into irrigation-helped by channels that canalize water from the most important rivers: Guadiana, Tagus and their tributaries. These infrastructures are now at the end of their functional lives and an opportunity exists to redesign water infrastructure for the next generation. The focus given in the dictatorship thought in solving problems at a large scale from a national point of view (top-down approach) seems to be inefficient today, since many of the problems can only be detected at the local level.

Currently, society is concerned about the use of freshwater; particularly in terms of quantity, quality, and hydro-politics. The main threats to water quantity find their base in global warming, irrigation malpractices, and over use of water in many arid areas. On top of this, water quality is threatened by pollution due to the large-scale mismanagement of the resource since the 19th century. This problem has been identified by society, and several European or even global-scale policies have been developed to counteract the trend of water resource misuse and deterioration. Several Sustainable Development Goals (SDGs) specifically aim to use water more sustainably: SDG 6 and 14 problems that the humankind must face [3,4]. These problems are particularly pressing in fragile areas with a transitional climate between arid and humid areas such as the Mediterranean Basin. The Mediterranean climate is characterized by the persistent presence of dry summers and an erratic temporal rainfall pattern where the amount of rainfall is increasingly reduced in a lower number of events [5].

The SW of Spain (Extremadura, Andalusia and Castilla-La Mancha regions) is a vast geographical area where the effects of global warming on erratic Mediterranean rainfall pattern are accompanied by the dominance of impermeable (siliceous) rocks such as shales and granites [6] and shallow soils (e.g., Leptosols and epileptic Cambisols) with scarce capacity of retaining water [7]. It means extreme events exceed the infiltration capacity of the soils and Hortonian flow occurs regularly, therefore, large quantities of water are lost as surface runoff, including the soil particles that are detached and the associated nutrients that are usually concentrated in the top $5 \mathrm{~cm}$ of soil $[8,9]$.

In addition to the erosion issues, the loss of water during rainfall events causes water scarcity in the dry period. This problem was attempted to be solved during the period of Franco's dictatorship (1939-1975) through an ambitious hydrological policy, which was based on the idea that no water was supposed to reach the sea. For this large reservoir, dams were built all over Spain that aimed to generate energy and to irrigate vast areas of traditionally rainfed crops [10]. In the case of Extremadura, this hydrological policy increased considerably the surface area aimed at irrigating confiscated farms, which their soils were developed on Tertiary (depth clayey soils commonly known in Spanish as Tierra de Barros) or alluvial sediments near Guadiana River through the construction of big channels of irrigation [11].

Extremadura has a population of about one million inhabitants (INE 2018) spread over an area of $41,635 \mathrm{~km}^{2}\left(25.7\right.$ people $\left./ \mathrm{km}^{2}\right)$, where $75 \%$ of people are living in municipalities below 10,000 inhabitants. Most large population centers (e.g., Badajoz, Mérida, Don Benito, Villanueva de la Serena, Plasencia, Coria, Navalmoral de la Mata, etc.,) are concentrated in the most productive agriculture areas [12] that coincide with the lands turned into irrigation during the dictatorship (fertile plains of the Guadiana River and some tributaries of the Tagus River such as Tiétar and Alagón rivers). The agriculture sector represents $10 \%$ of total employment and $8 \%$ of gross value added [13].

The regional system of reservoirs is composed by 174 dams that ranges from a maximum capacity of storing water lower than $10 \mathrm{hm}^{3}$ (134 out of them) up to $3219 \mathrm{hm}^{3}$ (La Serena's Reservoir). There are 60 dams, which are no longer used, 41 have a single use and 31 are used for a double proposal being water for home, irrigation and fishing the dominant uses. Only 65 reservoirs are now being used for the municipalities to supply water for home. In fact, most municipalities prefer to be supplied from 
small dams for home and to keep water from large reservoirs to irrigation and fishing, among other uses. In addition, 21 reservoirs are also used to produce electricity power being destined uniquely five of them in the Tagus River for this proposal.

The municipality of Arroyo de San Serván (Badajoz province) is a good example of a transitional place where the limit of the irrigated area using water from Guadiana River was defined during the dictatorship. It has meant a significant difference in the profitability of land depending on having the possibility, or not, to use water for irrigation in your farm, i.e., irrigated versus rainfed cultivation. In addition, the systems for irrigating have progressively increased in terms of technological complexity. This phenomenon is complimented by a change in production system from traditional crops such as maize and tomato to (super) intensive olive and vineyard plantations due to the loss of profitability of the traditional cropping systems.

According to Lonergan [3], the problem of water use must be dealt with by its quality, amount and political decisions. Regarding quality, the main problem with the rural areas in Extremadura is to guarantee adequate water quality for consumption, i.e., the user can drink water from the tap in optimal conditions. Large investments have been done by the local council to build deposits, a good distribution network and facilities to purify waste water before it is returned to the river. In spite of this enormous effort, commonly complaints from local users are received about the quality of water, the high price of the service, and also against the council because this service has been privatized in many places.

In terms of quantity, many farmers are not satisfied with their rights on water in terms both of the price per cubic meter they must pay and the amount they are allowed to use. In addition, there have been many conflicts about the quantity used by each individual farmer, which were tried to be solved by installing personal counters, which target at making farmers pay by their real consumption. Another recent factor of importance is the wide-spread implementation of private swimming pools during the economic boom of Spain (1998-2007) coupled with large investments in leisure facilities (e.g., sport pavilions, etc.). In the case of municipality of Arroyo de San Serván, a municipal Olympic swimming pool was built at the end of the 20th century to be used during summer. In the last 10 years, one municipal spa was built close to the sport pavilion forming a leisure complex. Regular users must pay a fee to be able to use these facilities.

In our study, we focus on local scale, which in Spain has been neglected as a relevant scale for sustainable water management. Therefore, taking into account the abovementioned, the main goal of this research was to better understand local problems related to water use in the Arroyo de San Serván municipality as a paradigmatic example in order to gather useful information that can be helpful for stakeholders and decision makers in land planning at different scales. Our methodology is based in a descriptive and exploratory approach to assess this problematic issue and come to a good understanding that will be crucial to be well-adapted to the challenges of this new millennium.

\section{Materials and Methods}

\subsection{Study Area}

The study was carried out in the municipality of Arroyo de San Serván (Badajoz province, Extremadura region, SW Spain), as seen in Figure 1. Its official population is 4126 inhabitants (2018) and its territory covers $50.1 \mathrm{~km}^{2}$, averaging a population density of 83 inhabitants $/ \mathrm{km}^{2}$. It is located in the center south of the Extremadura region at $15 \mathrm{~km}$ of Mérida, the capital of the region, on the left banks of the Guadiana River. Its southern limit is considered the beginning of the so-called Tierra de Barros, the main belt of wine production in the region. In fact, Arroyo de San Serván is considered by many geographers, as the place where Tierra de Barros starts. Local people mostly work in the services sector $(69.6 \%), 13.1 \%$ in agriculture, $12.6 \%$ in construction and $4.6 \%$ in the industry sector (INE, 2011).

From a physical point of view, Arroyo de San Serván is dominated by flat terrain with an average elevation between $200 \mathrm{~m}$ and $260 \mathrm{~m}$ a.s.l., surrounded by a mountainous area (Sierra de Arroyo, 
$600 \mathrm{~m}$ a.s.1.) in the eastern part of its territory. The northern half is irrigated, mostly located on soils developed on Quaternary alluvial sediments. In the southern part, mostly rainfed crops are farmed on soils developed in Tertiary sediments rich in clay. These characteristics have made agriculture one of the main economic activities in the municipality. Its cooperative is regionally famous by the significant amount of grapes and olives they gather every year at the end of each harvesting time.

The climate conditions are typically Mediterranean with a very dry and warm summer (average temperature: $26.4^{\circ} \mathrm{C}$, average rainfall: $32.4 \mathrm{~mm}$ ) and a total rainfall $(521.8 \mathrm{~mm})$ distributed throughout the fall, winter and spring seasons. Water for human consumption comes from the Guadiana River through a pipeline system until two water tanks where water is treated before being distributed to consumption. For irrigation, water comes from the Guadiana River through the channel of Lobón (left margin of the river). Some farmers also extract water from the aquifer to irrigate their farms (in both parts of the municipality). Urban wastewater is treated in a Wastewater Treatment Station (EDAR, acronym in Spanish) before it is discharged into the Tripero Stream (tributary of the Guadiana River).

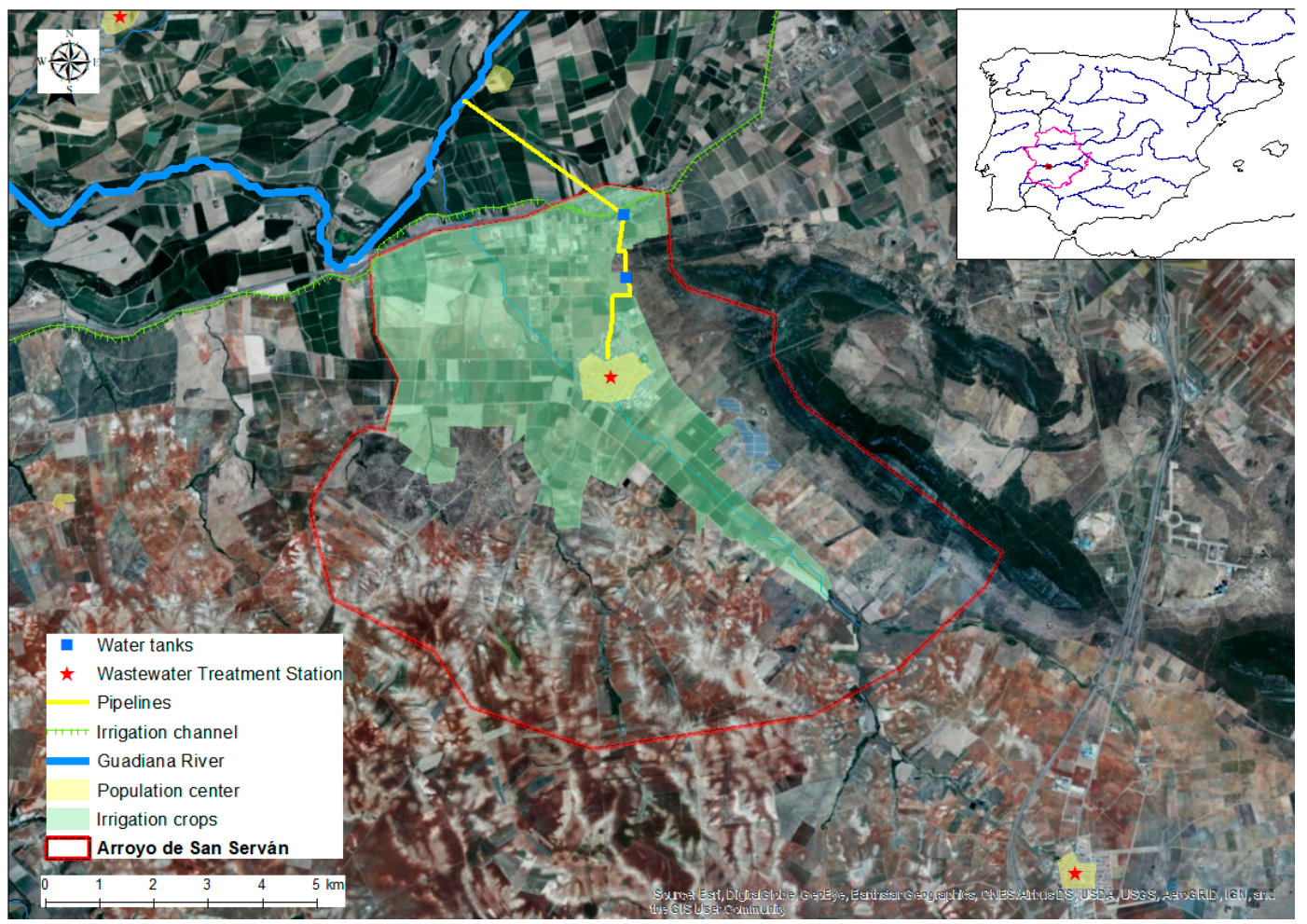

Figure 1. Geographical location of the study area: Municipality of Arroyo de San Serván (BA, ESP).

\subsection{Questionnaire Survey}

The study was based on the knowledge and perception of the people in the municipality of Arroyo de San Serván, about issues related to water use, as they have been observed by one of the authors who was born, grew up and has lived for more than 20 years in the studied municipality. The questionnaire was designed following several meetings between the authors of the manuscript and some invited scientists that provided their opinion. A draft version of the questionnaire was tested during 5 interviews in order to check the suitability of the questions. As a consequence, the final questionnaire was extended from 24 questions to 27 . All the questions were modified in order to obtain a Likert scale of 7 points. Finally, some questions were changed since one of the interviewees stated they were not easy to understand.

The final questionnaire was composed of 27 questions divided into 6 blocks: (1) characterization of the interviewee; (2) water use at home; (3) water use for agriculture; (4) water use for recreation; (5) agriculture intensification; and (6) water management. The answers mostly had multiple answers 
following a Likert scale from 1 to 7 [14]. In the case of domestic water, questions were mainly addressed to know the use of the tap water. The questions related to agriculture focused on the importance local people give to irrigated agriculture. Finally, leisure facilities were designed to get to know whether local people consider them a good investment or not.

Fieldwork, i.e., interviewing people in the street, was carried out during December 2018 and January 2019, taking advantage of the Christmas holidays where it is easier to find people in the street, supermarkets and other common places. The total number of surveyed people was 132 that supposed a level of confidence of around $90 \%$ and a precision of 3\% [15]. Most interviewees were happy and willing to be interviewed because they consider their opinion to be essential for the decision-making process. So, we can consider the information provided by the majority of people participated in the survey reliable.

\subsection{Data Analysis}

The data obtained were gathered in a Google Form designed for the research aimed at simplifying the process of the interview. Each question was treated as one variable and each interviewed as one case, so the dataset was a matrix of 132 cases and 27 variables. This information was summarized and treated statistically using statistical software Statistica version 6 [16].

Since the main goal of the research was descriptive and exploratory, the variables were treated by basic statistic parameters such as mean, median, minimum, maximum and standard deviation. In the case the answers comprised of categorical data, we used frequency tables to obtain the percentage of each class. Finally, when several options could be chosen at the same time, each option was treated separately.

The answers of each one of the 27 questions were coded in order to get quantitative data to find relationships between variables. Since they did not show a normal distribution they were first correlated between them using Spearman Rank Order Correlations. In those variables which were observed to have a high coefficient of correlation scatterplots were designed in order to detect any possible cause-effect relationship. The levels of significance considered were $p<0.05, p<0.01$ and $p<0.001$.

\section{Results}

\subsection{Domestic Use}

The target people (Table 1) were aimed to be representative in terms of gender, group of ages, and level of education. There was also great diversity in terms of professional skills.

Table 1. Main characteristics of the surveyed people.

\begin{tabular}{ccc}
\hline Genre & Age & Education \\
\hline Male $(28.8 \%)$ & $<24$ years old $(22.7 \%)$ & Primary studies $(18.9 \%)$ \\
Female $(71.2 \%)$ & $25-35$ years old $(28.8 \%)$ & School graduate $(36.4 \%)$ \\
& 36-45 years old $(24.2 \%)$ & High School $(15.9 \%)$ \\
& 46-60 years old $(21.2 \%)$ & University $(28.8 \%)$ \\
& $>60$ years old $(3.0 \%)$ & \\
\hline
\end{tabular}

The problem of water use at home was addressed by seven questions: [q6] quality of tap water (mark: 1-7); [q7] uses of tap water (multiple choice): water plants, water for pets, washing dishes, personal cleanliness, cook, and drink; [q8] do you drink tap water? Never (so I buy water in the supermarket), always, always but filtered; [q9] why do you not drink tap water? (Multiple choices) bad taste, smells bad, too much lime; [q10] in that does you base your reasons on? Nobody, common thought, local servants, I have seen data; [q11] price per month of water at home; and [q12] degree of satisfaction of the service taken into account the price paid (mark: 1-7). 
Figure 2 shows the comparison between the mean price (normalized at a scale between 1 and 7 from five intervals of price per month: < 30 EUR, 31-40 EUR, 41-50 EUR, 51-60 EUR, and > 60 EUR) paid by each interviewee and the quality of the water tap and degree of satisfaction expressed in the interviews (scale: 1-7). The degree of satisfaction was positively correlated to the quality of the water tap (r: 0.347, p < 0.001) and negatively with the price paid monthly by the service (r: -0.205 , $\mathrm{p}<0.05$ ). Nevertheless, only $10 \%$ of surveyed people pay more than 60 EUR per month for the service and most of them not consider expensive the price. Water quality was better assessed than the degree of satisfaction.

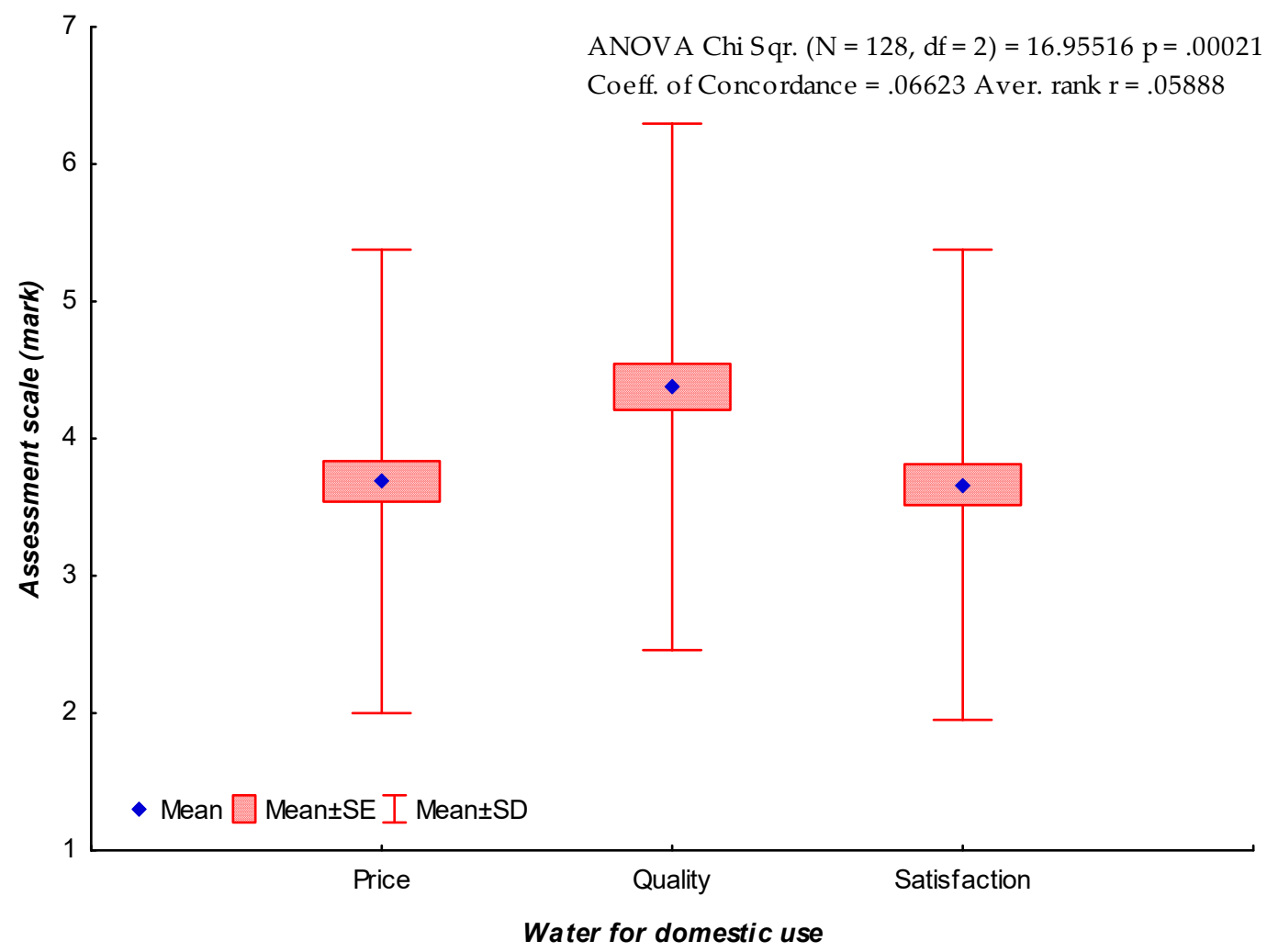

Figure 2. Box and whisker plot comparing price, quality and degree of satisfaction of water tap.

Regarding consumption, only one-third of the interviewed state to drink water from the tap directly, although it is commonly used for other uses such as watering ornamental plants (usually in vases), water for their pets, washing dishes, personal hygiene and cooking (64.4\%). Another 20\% drink water tap but make use of filter systems prior to consumption. The remaining $54 \%$ never drink water from the tap and $43.2 \%$ of this group buys bottles of water in the supermarket. The reasons given for these decisions are in $82.1 \%$ the people that they think water tap has a high content of calcium, while $64.2 \%$ argue it has a bad taste and even $9.5 \%$ says water tap smells bad. Curiously, only $18.1 \%$ of them recognize to have seen any data or have spoken with someone belonging to the local council. Nonetheless, $81.9 \%$ consider that this low quality of the tap water is a common belief among the people of Arroyo de San Serván.

\subsection{Water for Irrigation}

The local interest for the water used for irrigation agriculture was covered by four questions (scale: 1-7) that tried to obtain the perception of the local people on significant matters such as [q13] the level of importance of irrigation as source of inputs for families, and [q14] as source of employment. Furthermore, we asked about [q15] the level of satisfaction with the current price of water for irrigation (i.e., canon that must be paid to the Guadiana River Confederation) and [q16] with the recent installation of individual counters aimed at avoiding an overuse for some farmers and more efficient management. 
Figure 3 shows the comparison between the mean values given by the participant regarding some aspects such as the generation of employment and inputs or the level of satisfaction about the current price and management of water for irrigation. People consider irrigated agriculture highly favorable, as a way of generating employment, i.e., giving hours of work for the regular inhabitants. Nevertheless, this perception is not so high regarding the inputs. Although people are moderately satisfied with the installation of individual counters, there is a low level of satisfaction with the current price of water for irrigation $\left(0.02 \mathrm{EUR} / \mathrm{m}^{3}\right)$.

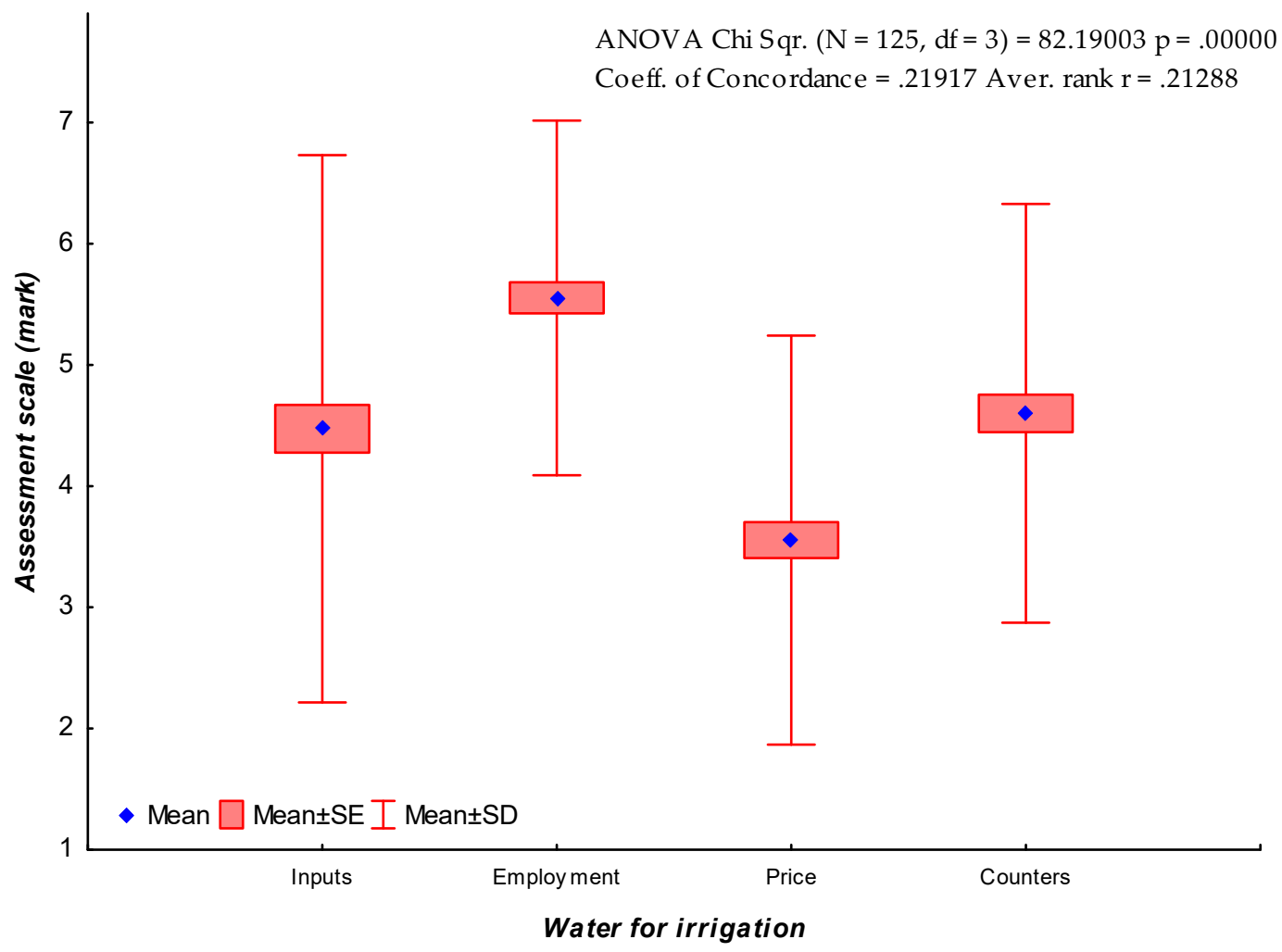

Figure 3. Box and whisker plot comparing the level of importance/satisfaction of local people regarding inputs and employment generated by irrigated agriculture and with the current price of water for irrigation and the recent installation of individual counters in every farm.

A positive correlation was found between the generation of employment and inputs (r: 0.465, $p<0.001$ ), as well as between the level of satisfaction with the current price and the installation of individual counters ( $\mathrm{r}: 0.294, \mathrm{p}<0.001$ ). There was no mention about a possible reduction in terms of inputs or employment driven by the current price of the service but correlations were found between the level of satisfaction with the installation of individual counters and inputs ( $\mathrm{r}: 0.325, \mathrm{p}<0.001$ ) and employment $(\mathrm{r}: 0.279, \mathrm{p}<0.01)$. No significant correlations were found between price and employment (r: 0.026).

\subsection{Leisure Facilities}

Nowadays, Arroyo de San Serván has 65 private swimming pools (1 by each 63 people) mainly distributed in three new neighborhoods built in areas disconnected to the main settlement where most people are living according to the information observed from the orthophotos of 2016 (freely available on Internet: centrodedescargas.cnig.es).

The perception on the wide-spread implementation of private swimming pools and the recent construction of the municipal spa was addressed by three questions. Q17 asks about the necessity of having private pools and Q18 about the necessity of having a municipal spa using a scale from 1 to 7. Q19 asks about the benefits of having a municipal spa more concretely giving the possibility of 
choosing between multiple options: (1) it is generating debts in the municipal coffers, (2) it does not provide anything, (3) it provides entertainment for local people, (4) it provides inputs for the council, (5) it is generating employment, (6) it attracts tourists and (7) it improves our quality life.

Figure 4 shows in a column graph, the percentage of people that agree with some negative/positive effects of the construction and current use/management of the municipal spa. Broadly speaking, people consider the installation of this leisure facility quite positive. For instance, ca. $60 \%$ consider it is providing entertainment and employment for local people and it is a good tourism attraction for "sharing" or "stealing" visitors to the city of Mérida. Less than $20 \%$ of people think this spa is not generating anything $(8.5 \%)$ or even it is generating debts for the local economy $(14.0 \%)$. Around $40 \%$ of people think the spa is helpful to improve their quality of life and it is a good source of income for the local council.

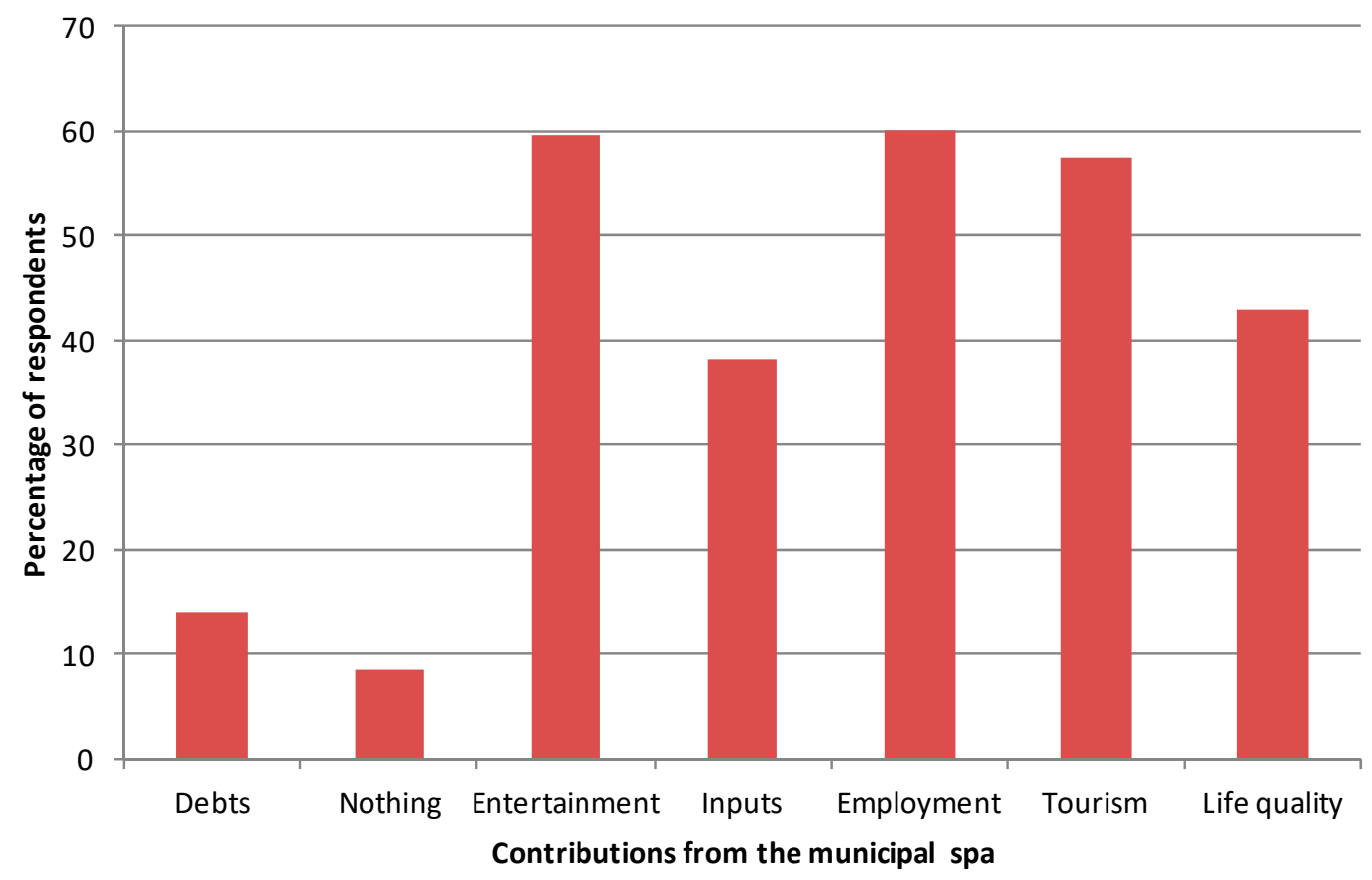

Figure 4. Percentage of people who think about negative/positive effects of the use of the municipal spa.

Regarding the wide-spread implementation of private swimming pools, most people think they have not been so necessary (mean value: 3.6 out of 7 ) although there was a great variability in the responses (SD: 2.1). Some local agents consider that private swimming pools are provoking higher expenses in water and they are progressively reducing the number of tickets that the local council sell in summertime for the municipal swimming pool. On the other hand, some inhabitants that are living in the quarter where private swimming pools are common argue the consumption of water is not so high and the reduction in the number of tickets to sell is anecdotic because of the small size of these private swimming pools.

\subsection{Agricultural Intensification: Benefits, Problems and Management}

A regular farm irrigated by a drip irrigation system has an average consumption between $3500-6000 \mathrm{~m}^{3} /$ ha in superintensive vineyards and olive orchards, while for maize (Zea mays) the consumption increases between $5500-7000 \mathrm{~m}^{3} / \mathrm{ha}$. This consumption is higher in case of irrigation system by sprinklers $\left(8500-9000 \mathrm{~m}^{3} / \mathrm{ha}\right)$ and by gravity $\left(11,500-12,000 \mathrm{~m}^{3} / \mathrm{ha}\right)$. Since many farmers are changing to drip irrigation, the trend is a lower consumption of water per hectare but farmers are increasing the surface of cultivated land (personal interview with a regular farmer).

The recent conversion of irrigated areas that were traditionally cultivated by maize and tomato into (super) intensive olive tree and vineyard orchards has brought benefits, problems and management 
challenges that we have tried to cover in eight questions in our questionnaire. Q20 asked about the economic benefits of this abovementioned intensification, Q21 about the ecological effects and Q22 about the convenience of using this kind of agriculture in spite of a presumable higher consumption of water and potential ecological conflicts. Q23 asks about the perception of the (over) use of pesticides, herbicides and fertilizers in these orchards. Finally, Q24 and Q26 have aimed at identifying environmental and management problems, respectively. Q25 and Q26 have gathered the perception of necessity of solving these detected problems in the previous questions.

Figure 5 shows the values as they were scored by the interviewees for many environmental and management concerns related to agricultural intensification, i.e., people are more worried when values get larger. They admit the positive effects on local economy of this recent (re)intensification but they also recognize it is negatively affecting the environment through a higher consumption of water and (in) direct pollution by concentration of polluters such as herbicides, pesticides and fertilizers. In fact, this kind of agriculture is not accepted as very beneficial for the environment. These problems detected should be ameliorated through some improvements in the management, particularly in that focused on the environmental problems since local people considered water management is less preoccupant in terms of solving problems. Regarding the environmental problems detected, some can be highlighted such as water pollution, reduction in the number of bees, birds and hunting animals, etc. In terms of water management, local people think it is necessary to reduce supply cuts, clean bedrocks and effectively measure against soil erosion, water loss and floods.

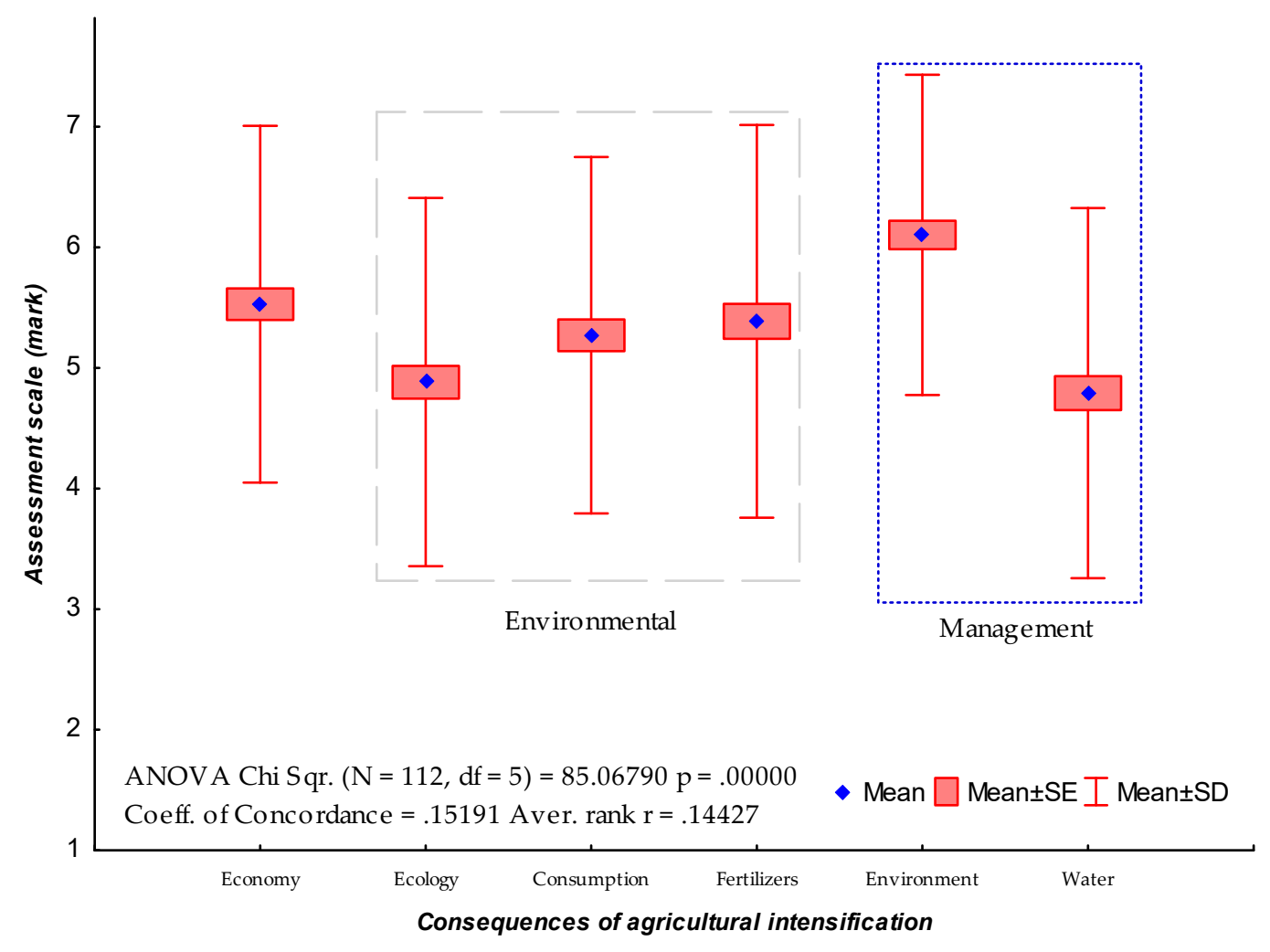

Figure 5. Comparison of mean values of the degree of importance that local people gave to the effects of intensification on (left to right) economy, ecology, water consumption, overuse of agricultural products, as well as on the necessity of improvements in the environmental and water managements.

\section{Discussion}

The region of Extremadura is a paradigmatic case in terms of water use and management since it stores 30\% of total water dammed in Spain [1]. Nevertheless, this theoretical abundance does not hide several problems of management that they are currently affecting mainly on rural areas. In many cases, these problems cannot be solved because they are not still detected. In this work, we have found 
a representative municipality where local people have been asked about regular problems related to water that they are affecting at home, at work and in their free time.

The access to safe drinking water is a basic human right according to the United Nations World Health Organization (WHO) [17]. In the case of developed countries such as Spain, this access is ca. $100 \%$ guaranteed to every settlement; although it is supposing a big effort by all the administrations, particularly local councils that have to guarantee its correct distribution and to control the consumption of each individual by counters and putting a price for the service [18]. In addition, each settlement has to have a sewage treatment plant that purifies water before it is returned to the rivers, streams and the sea [19]. In fact, Spain has been already fined twice by the European Union for bad wastewater treatment since the rules of the Directive on wastewater treatment (Council Directive 91/271/EEC of 21 May 1991 concerning urban waste-water treatment) is not being fully complied since 2011.

In spite of this effort, many citizens refuse to drink tap water and they spend a lot of money in buying bottles of water in the supermarket. In the case studied here, we have detected the paradox of people arguing about the price of water at home but they are going to the supermarket to buy bottles. The plenary session of the European Parliament (celebrated on 23 October 2018) approved a set of measures to increase consumer confidence in tap water and thus reduce the consumption of bottled water, which is so damaging to the environment. These measures will suppose a modification of the current Drinking Water Directive (Council Directive 98/83/EC of 3 November 1998 on the quality of water intended for human consumption) concerns the quality of water intended for human consumption as a result of the citizen initiative "Right2Water" [20].

About $90 \%$ of the people interviewed spend less than 60 EUR per month on water at home. This price could be considered acceptable taking into account that Spain is a Mediterranean country where water is a scarce resource and it is far away from the real price to cover costs of network maintenance [21]. Nevertheless, many people could consider a high price taking into account that Extremadura region gathers ca. $30 \%$ of dammed water in the whole country. According to the Spanish Statistical Institute (INE) the price for water at home (industry and service sectors are included) in 2016 ranged from $1.16 € / \mathrm{m}^{3}$ in Castilla y León to $2.69 € / \mathrm{m}^{3}$ in Catalonia (mean values by region), i.e., prices have been multiplied by 3 and 4 since 2000. The price for water at home in Spain is indeed generally lower than that paid by the majority of the European Union countries (Official Statistics, source: EurEau).

In Extremadura, there are still clear economic differences between settlements that have benefited from the presence of irrigation and others that still survive with rainfed crops and livestock husbandry. This fact is, one of the reasons local people consider the possibility of having irrigation as the only way of development, i.e., the only way to escape from the poor conditions of areas with traditional rainfed agriculture [22]. This argument is supported by the perception of the interviewed local people that consider irrigation as something positive for employment and inputs, although they are not satisfied with the current price of the service. Furthermore, some citizens of Arroyo de San Serván in informal conversations after the interviews expressed us their dissatisfaction about the expansion plan of the irrigated perimeter of Tierra de Barros in 46,252 ha (Decree 11/2018, of January 30, by which the perimeter of the irrigable zone "Tierra de Barros" is extended, the General Plan of Transformation is approved in irrigation, and this transformation is declared of interest to the Autonomous Community, Under Article 112 of the Agrarian Law 6/2015, of March 24, of Extremadura) that it will not affect to this municipality.

A new challenge that many territories are now facing is the re-intensification, i.e., changing the traditional irrigated crops into orchards with smart systems of irrigation and harvesting by machinery [23]. From an economic point of view, local people are also considering these practical as positive but they are aware of the environmental problems that it can generate (less animals, water pollution, etc.) [24]. In fact, they express the necessity of taking measurements that buffer these effects. Other problem highlighted by Perry et al. [25] is the higher water consumption at catchment scale when more efficient systems of irrigation begin to be installed in the farms, i.e., the use of water 
is increasingly efficient at a farm scale but it masks an overuse of the resource since it is now much more productive.

The use of high demanding facilities in water such as a municipal spa is mostly well-accepted by local people that observe it as another possibility of generating employment and inputs, as well as entertainment for them [26]. This necessity of employment in many rural areas can be one of the reasons for local people to be less worried about topics such as an optimum consumption of water. In fact, the rural areas of SW Spain are commonly known by their high unemployment rates and by problems such as depopulation or aging [27]. These kinds of facilities can become a tourism attraction since Arroyo de San Serván is located $16 \mathrm{~km}$ away of Mérida (estimated by Google Maps from the National Museum of Roman Art of Mérida to the Municipal Spa of Arroyo de San Serván), the second tourism destination of the region (after Cáceres) visited by 287,207 tourists in 2018 [28].

Another topic which is always controversial is the price for water both at home and for agriculture or leisure activities $[29,30]$. In rural locations of not yet industrialized areas, the price of water will be a potential problem for local consumers that will presumably consider the price they must pay expensive. In fact, there are many municipalities that local politicians could be worried by the less popular effect of increasing the "water bill" although it can be supposed lost in the local annual budget [31]. The price of water for agriculture (and at home as well) of $0.02 € / \mathrm{m}^{3}$ in Arroyo de San Serván is actually quite low, very distant to $0.35 € / \mathrm{m}^{3}$ that some agriculturers from Murcia Region must pay. Regarding the use of private swimming pools in many houses, Hurd [32] quantified ca. $50 \%$ of consumption of water at home is dedicated to the external parts of the house, i.e., swimming pool and garden. So, the neighborhoods built in the 21st century will be large consumers of water.

From the agricultural point of view, farmers are increasingly worried about the low price of their products coupled with higher expenses in agricultural products, taxes and also in the canon of water $[33,34]$. So, they begin to be concerned in the searching of new formulas of plantation, harvesting and marketing that allow more sustainable practices for their farms. They do not need to spend a lot of money on resources that are increasingly scarce [35]. The new systems of cropping/planting are progressively reducing the necessity of the labor force during the harvesting period, although they can generate many days of labor (jornales in Spanish) in other periods of the agrarian cycle. Nevertheless, the use of more complex tools (e.g., tractors equipped by GPS) will need workers with high expertise and it can suppose the loss of many jobs according to the effects of robotization foreseen by the OECD (Organisation for Economic Co-operation and Development).

\section{Conclusions}

This study expresses the perception of local communities about water use and management in rural areas of SW Spain where local problems are not usually noticeable. The results found reflect a generalized refusal of regular people of drinking water from the tap in spite of being guaranteed its quality by local governments, i.e., they prefer to spend extra money on drinking water in supermarkets or buying expensive filtering systems. In addition, local people have well-accepted the implementation of the irrigated agriculture and leisure that have high demands in terms of water. They are more worried about facts, as the generation of employment rather than by the sustainability of the water as a valuable resource. Nonetheless, this study reflects the necessity of investigating problems on water use from a local perspective since they are the first agents capable to identify regular problems usually forgotten by the decision makers.

Author Contributions: Conceptualization, M.P., J.B.-G., A.A.-T., R.R.-R., S.K.; methodology, M.P., J.B.-G., A.A.-T., R.R.-R., S.K.; validation, M.P., J.B.-G., R.R.-R.; formal analysis, M.P., J.B.-G., A.A.-T.; writing-original draft preparation, M.P.; writing-review and editing, S.K., M.P.; supervision, S.K.

Funding: This work has been financially supported by the Research Project IB16052 "Desarrollo de un sistema de evaluación integral espacialmente distribuido para explotaciones de ganadería extensiva" funded by Junta de Extremadura (Regional Government of Extremadura) and European Fund of Regional Development (European Union). 
Acknowledgments: We thank the comments of two anonymous reviewers that they have helped considerably to improve our manuscript and they gave us useful suggestions for further research.

Conflicts of Interest: The authors declare no conflict of interest.

\section{References}

1. Junta de Extremadura. Plan Turístico de Extremadura 2017-2020; Dirección General de Turismo: Mérida, Spain, 2016; pp. 40-46.

2. García Marín, R.; Mateos Rodríguez, A.B. El clima de Extremadura. In Aportaciones a la Geografía Física de Extremadura con Especial Referencia a las Dehesas; Schnabel, S., Lavado Contador, J.F., Gómez Gutiérrez, Á., García Marín, R., Eds.; Fundicotex: Cáceres, Spain, 2010; pp. 25-52.

3. Lonergan, S.C. Water and Conflict: Rhetoric and Reality. In Environmental Conflict; Routledge: London, UK, 2018; pp. 109-124.

4. Griggs, D.; Stafford Smith, M.; Rockström, J.; Öhman, M.C.; Gaffney, O.; Glaser, G.; Kanie, N.; Noble, I.; Steffen, W.; Shyamsundar, P. An integrated framework for sustainable development goals. Ecol. Soc. 2014, 19, 49. [CrossRef]

5. Schnabel, S. Soil Erosion and Runoff Production in a Small Watershed under Silvo-Pastoral Land Use (Dehesas) in Extremadura, Spain; Geoforma Ediciones: Logroño, Spain, 1997; p. 167.

6. Pulido Fernández, M.; Lavado Contador, J.F.; Schnabel, S.; Gómez Gutiérrez, Á.; Lozano-Parra, J. Changes in land management of Iberian rangelands and grasslands in the last 60 years and their effect on vegetation. In Vegetation; Sebata, A., Ed.; IntechOpen: London, UK, 2018; pp. 24-42.

7. Pulido, M.; Schnabel, S.; Contador, J.F.L.; Lozano-Parra, J.; Gómez-Gutiérrez, Á. Selecting indicators for assessing soil quality and degradation in rangelands of Extremadura (SW Spain). Ecol. Indic. 2017, 74, 49-61. [CrossRef]

8. $\quad$ Ferreira, C.; Walsh, R.; Shakesby, R.; Keizer, J.; Soares, D.; González-Pelayo, O.; Coelho, C.; Ferreira, A. Differences in overland flow, hydrophobicity and soil moisture dynamics between Mediterranean woodland types in a peri-urban catchment in Portugal. J. Hydrol. 2016, 533, 473-485. [CrossRef]

9. Hueso-González, P.; Ruiz-Sinoga, J.; Martínez-Murillo, J.; Lavee, H. Overland flow generation mechanisms affected by top soil treatment: Application to soil conservation. Geomorphology 2015, 228, 796-804. [CrossRef]

10. Swyngedouw, E. Technonatural revolutions: the scalar politics of Franco's hydro-social dream for Spain, 1939-1975. Trans. Inst. Br. Geogr. 2007, 32, 9-28. [CrossRef]

11. López-Gunn, E.; Mayor, B.; Dumont, A. Implications of the modernization of irrigation systems. In Water, Agriculture and the Environment in Spain: Can we Square the Circle? De Stefano, L., Ramón Llamas, M., Eds.; CRC Press: Boca Raton, FL, USA, 2012; pp. 241-253.

12. Nieto Masot, A.; Cárdenas Alonso, G. El Método Leader como política de desarrollo rural en Extremadura en los últimos 20 años (1991-2013). Boletín de la Asociación de Geógrafos Españoles 2015, 69, 139-162.

13. Nieto Masot, A.; Gurría Gascón, J.L. Las políticas rurales europeas y su impacto en Extremadura. Boletín de la Asociación de Geógrafos Españoles 2008, 48, 225-246.

14. Croasmun, J.T.; Ostrom, L. Using Likert-Type Scales in the Social Sciences. J. Adult Educ. 2011, 40, 19-22.

15. Israel, G.D. Determining Sample Size. Fact Sheet PEOD-6 1992, November 1992; University of Florida: Gainesville, FL, USA, 1992; pp. 1-5.

16. STATISTICA; StatSoft. Inc.: Tulsa, OK, USA, 2001; Version 6; Data Analysis Software System.

17. World Health Organization (WHO). Guidelines for Drinking-Water Quality; World Health Organization (WHO): Geneva, Switzerland, 2011; pp. 104-108.

18. Saurí, D.; Del Moral, L. Recent developments in Spanish water policy. Alternatives and conflicts at the end of the hydraulic age. Geoforum 2001, 32, 351-362. [CrossRef]

19. Esteban, R.I.; de Miguel, E.O. Present and future of waste water reuse in Spain. Desalination 2008, 218, 105-119. [CrossRef]

20. Parks, L. Framing in the Right2Water European citizens' initiative. In Proceedings of the ECPR General Conference, Glasgow, UK, 3-6 September 2014; pp. 1-20.

21. González Gómez, F. El precio del agua en las ciudades. Reflexiones y recomendaciones a partir de la Directiva 2000/60/CE. Ciudad y Territorio 2005, 37, 305-320. 
22. Barbero, Á. The Spanish national irrigation plan. In Water and Agriculture: Sustainability, Markets and Policies; OECD Publishing: Paris, France, 2006; pp. 427-436.

23. Tous, J.; Romero, A.; Hermoso, J. New trends in olive orchard design for continuous mechanical harvesting. Adv. Hortic. Sci. 2010, 24, 43-52.

24. Miranda-Fuentes, A.; Rodríguez-Lizana, A.; Gil, E.; Agüera-Vega, J.; Gil-Ribes, J.A. Influence of liquid-volume and air flow rates on spray application quality and homogeneity in super-intensive olive tree canopies. Sci. Total Environ. 2015, 537, 250-259. [CrossRef] [PubMed]

25. Perry, C.; Steduto, P.; Allen, R.G.; Burt, C.M. Increasing productivity in irrigated agriculture: Agronomic constraints and hydrological realities. Agric. Water Manag. 2009, 96, 1517-1524. [CrossRef]

26. Hall, M. Spa and health tourism. In Sport and Adventure Tourism; Hudson, S., Ed.; Taylor and Francis: London, UK, 2012; pp. 298-317.

27. Cárdenas Alonso, G.; Nieto Masot, A. Towards Rural Sustainable Development? Contributions of the EAFRD 2007-2013 in Low Demographic Density Territories: The Case of Extremadura (SW Spain). Sustainability 2017, 9, 1173. [CrossRef]

28. Sánchez-Oro Sánchez, M.; Nieto Masot, A.; Fernández Portillo, A.; García, Y.; Cárdenas Alonso, G. Memoria Turística de Extremadura por territorios; Universidad de Extremadura: Cáceres, Spain, 2019.

29. Ruiz-Villaverde, A.; García-Rubio, M.A. Public participation in European water management: From theory to practice. Water Resour. Manag. 2017, 31, 2479-2495. [CrossRef]

30. Suarez-Varela, M.; Martínez-Espiñeira, R. A proposal for the analysis of price escalation within water tariffs: The impact of the Water Framework Directive in Spain. Environ. Plan. C Politics Space 2018, 36, 726-749. [CrossRef]

31. Martinez-Espiñeira, R.; García-Valiñas, M.A.; González-Gómez, F. Does private management of water supply services really increase prices? An empirical analysis in Spain. Urban Stud. 2009, 46, 923-945. [CrossRef]

32. Hurd, B.H. Water conservation and residential landscapes: Household preferences, household choices. J. Agric. Resour. Econ. 2006, 31, 173-192.

33. Berbel, J.; Gómez-Limón, J.A. The impact of water-pricing policy in Spain: an analysis of three irrigated areas. Agric. Water Manag. 2000, 43, 219-238. [CrossRef]

34. Varela-Ortega, C.; Sumpsi, J.M.; Garrido, A.; Blanco, M.A.; Iglesias, E. Water pricing policies, public decision making and farmers' response: implications for water policy. Agric. Econ. 1998, 19, 193-202. [CrossRef]

35. Varela-Ortega, C.; Blanco-Gutiérrez, I.; Esteve, P.; Bharwani, S.; Fronzek, S.; Downing, T.E. How can irrigated agriculture adapt to climate change? Insights from the Guadiana Basin in Spain. Reg. Environ. Chang. 2016, 16, 59-70. [CrossRef]

(C) 2019 by the authors. Licensee MDPI, Basel, Switzerland. This article is an open access article distributed under the terms and conditions of the Creative Commons Attribution (CC BY) license (http://creativecommons.org/licenses/by/4.0/). 